\title{
Comparison of reverse-transcription loop-mediated isothermal amplification and reverse-transcription polymerase chain reaction for grass carp reovirus
}

\author{
Shuixian Yang ${ }^{1}$, Kai-Yu Wang ${ }^{1}$, Zexiao Yang ${ }^{2}$ \\ Sichuan Agricultural University, College of Veterinary Medicine, ${ }^{1}$ Department of Basic Veterinary Medicine, \\ ${ }^{2}$ Department of Animal Quarantine Inspection, Sichuan, China \\ Received October 8, 2014 \\ Accepted April 1, 2015
}

\begin{abstract}
Grass carp reovirus (GCRV) has been assigned to a newly established Aquareovirus genus in the family of Reoviridae which leads to haemorrhagic disease and extremely high mortality rate in grass carp. In this study, comparison was made between the novel one-step reverse transcription loop-mediated isothermal amplification (RT-LAMP) and the reverse transcription polymerase chain reaction (RT-PCR) for detection of grass carp reovirus. The result indicated that RT-LAMP had $\times 10$ higher sensitivity comparable to RT-PCR. The specificity of the two methods for GCRV detection were both developed successfully by other three aquatic viruses. In the field trial, both RT-PCR and RT-LAMP methods were applied to detect the samples from different infected organs and tissues. The result demonstrated that RT-LAMP had a high accuracy to confirm the diagnosis as well as the RT-PCR. This study showed that the RT-LAMP, compared to the RT-PCR, was simple, time-saving, convenient, but required specificity primers and possibly generated false positive product. Its products, unlike RT-PCR, could not be direcly used in further molecular research after purification. Thus RT-LAMP might be an optimal diagnostic method for rapid and preliminary diagnosis of GCRV infection in resource-limited setting situation.
\end{abstract}

Comparison, RT-PCR, one-step RT-LAMP, GCRV

Grass carp reovirus (GCRV) is a tentative member of the Aquareovirus genus in the family Reoviridae, mainly infecting grass carp (Ctenopharyngodon idella) (Ma et al. 2011), which is one of the most promising species for aquaculture in China ( $\mathrm{Su}$ et al. 2009; Ma et al. 2011). Because of the rapid spread and difficulty of treatment in freshwater aquaculture, GCRV causes a high mortality rate (about $80 \%$ ) and enormous economic loss every year (Zhang et al. 2012). In terms of controlling the spread of infection, several immune diagnostic methods have been developed. The infection continues to occur. Therefore, earlier detection and effective prevention of GCRV play a crucial role in preventing and controlling its outbreaks.

So many current methods have been used to diagnose the GCRV, including antigenrelated serological reactions, genome-related nucleic acid hybridization (Rangel et al. 1999), reverse transcription-polymerase chain reaction (RT-PCR) techniques and realtime RT-PCR (Zhou et al. 2011; Zhang et al. 2012). Real-time PCR has been considered to be the "golden standard" for accurate, sensitive, and rapid measurement for target sequence amplification (Watzinger et al. 2006). It has been broadly used for detecting and monitoring infections and aquatic viral load; however, these techniques require centralized laboratory facilities and clinical specimen submissions that might delay disease diagnosis. In recent years, an elegant and innovative technique called the loop-mediated isothermal amplification (LAMP) method has been successfully applied for detecting many kinds of aquatic bacteria and virues, such as Flavobacterium psychrophilum (Fujiwara and Eguchi 2009), Vibrio alginolyticus (Cai et al. 2010), haematopoietic necrosis virus (IHNV) (Gunimaladevi et al. 2005), haemorrhagic septicaemia virus (VHS) (Soliman

Address for correspondence:

Kai-Yu Wang

Department of Basic Veterinary Medicine

College of Veterinary Medicine

Sichuan Agricultural University, Sichuan, China

Phone: +86-0835-2885753

Fax: +86-0835-2885302

E-mail: kywangsicau@126.com

http://actavet.vfu.cz/ 
and El-Matbouli 2006), yellow head virus (YHV) (Mekata et al. 2006), spring viraemia of carp virus (SVCV) (Shivappa et al. 2008), and white spot syndrome virus (Jaroenram et al. 2009). The RT-LAMP, utilizing two sets of primers including two inner primers and two outer primers, are specific for six independent regions of the target sequence. A large amount of magnesium pyrophosphate is produced during the reaction, so the amplified products can be easily observed by the naked eye or judged visually by the colour change after the addition of nucleic acid stain (SYBR Green I) (Notomi et al. 2000). The purpose of this study was to establish an RT-LAMP method for GCRV that could be used as a diagnostic method in laboratories with limited equipment, especially under field conditions. Comparing the RT-LAMP with RT-PCR, the specificity and sensitivity of the two methods were assessed, and the applicability as diagnostic test was evaluated.

\section{Materials and Methods}

RNA extraction and viral strains

Ribonucleic acid was extracted from the liver and spleen of the clinical grass carp samples, which were collected from Meishan farms in the Sichuan Province, using a commercial RNA Rapid Extraction Kit (Bio Teke, Beijing, China). Spring viraemia of carp virus (SVCV), haemorrhagic septicaemia virus (VHS) and koi herpesvirus (KHV) were provided by Dr. Q. Wang. (Department of Basic Veterinary Medicine, College of Veterinary Medicine, Sichuan Agricultural University, Ya'an, Sichuan, China). The cDNA was obtained by the PrimeScript II 1st Strand cDNA Synthesis Kit (TAKARA, Dalian, China).

Primers design

Primers design was based on the target GCRV sequences from GenBank, aligned using ClustalW to find a well-conserved region within the gene (accession no. VP7/AF236688). A set of five primers was designed for RTLAMP assay using the online LAMP primer design software Primer Explorer V4 and RT-PCR primers displayed the location of oligonucleotide primers in the target sequence (Table 1).

Table 1. Details of RT-PCR and RT-LAMP primers designed for detection of VP7 gene sequence of GCRV. Genome position depending on GCRV VP7 (225-569) gene sequence (GenBank accession no. AF236688). The primers of VP7-F and VP7-R were for RT-PCR primers, VP7-F3, VP7-B3, VP7-FIP, VP7-BIP, and VP7-LB were applied in RT-LAMP.

\begin{tabular}{|c|c|c|c|}
\hline Method & Primer & Type & Sequence (5'to 3') \\
\hline \multirow[t]{2}{*}{ RT-PCR } & $\mathrm{F}$ & Forward primer & 5'-TCAAGACTCCCACGCTTGTTC-3' \\
\hline & $\mathrm{R}$ & Reverse primer & 5'-TGCGTATCGTCCAACGGTTT-3' \\
\hline \multirow[t]{5}{*}{ RT-LAMP } & $\mathrm{F} 3$ & Forward outer primer & 5'-TGGATGTGAAAGCTGGGTTC-3' \\
\hline & B3 & Backward outer primer & 5'-GGGATGCTCGTTAGGCAATT-3' \\
\hline & FIP & Forward inner primer & $\begin{array}{l}\text { 5'-GGTGCGAAACGGAAGTTCGACGCC } \\
\text { CCAACTGCCGATGAAAC-3' }\end{array}$ \\
\hline & BIP & Backward inner primer & $\begin{array}{c}\text { 5'-ACGATTCCTCTGCTACCGCTTG } \\
\text { AAAGGATCGGGAGGTGGAT-3' }\end{array}$ \\
\hline & LB & Backward loop primer & 5'- ATCACTGCCAGGCCGGTCA-3' \\
\hline
\end{tabular}

GCRV: grass carp reovirus; RT-PCR: reverse-transcription polymerase chain reaction; RT-LAMP: reversetranscription loop-mediated isothermal amplification

\section{RT-PCR and optimization of reaction condition}

The RT-PCR was performed in a total volume of $25 \mu$ l containing the cDNA template $(2 \mu \mathrm{g})$, primers $\mathrm{F}$ and R ( $2 \mu \mathrm{M} /$ each), $2.5 \mathrm{mM}$ of dNTPs (Takara Biotechnology, Dalian, China), $25 \mathrm{mM} \mathrm{MgCl}$, Taq DNA polymerase (5 U/ $\mu$ l) (Takara Biotechnology, Dalian, China), $10 \times$ PCR buffer consisting of $20 \mathrm{mM}$ Tris- $\mathrm{HCl}, 10 \mathrm{mM} \mathrm{KCl}$, $10 \mathrm{mM}\left(\mathrm{NH}_{4}\right)_{2} \mathrm{SO}_{4}, 2 \mathrm{mM} \mathrm{MgCl}, 0.1 \%$ Triton X-100 (HaiGene, Harbin, China), and ddH O. The RT-PCR reaction mixture was incubated in an initial denaturation at $94{ }^{\circ} \mathrm{C}$ for $5 \mathrm{~min}$; followed by 35 cycles of denaturation at $94{ }^{\circ} \mathrm{C}$ for $45 \mathrm{~s}$, annealing at $53{ }^{\circ} \mathrm{C}$ for $45 \mathrm{~s}$, extension at $72{ }^{\circ} \mathrm{C}$ for $45 \mathrm{~s}$; finally extension at $72{ }^{\circ} \mathrm{C}$ for $10 \mathrm{~min}$. The amplicon was analyzed in 1\% agarose gel electrophoresis stained with ethidium bromide. In order to optimise the assay, the reaction conditions, including the dosage of template, primers, dNTPs, Taq DNA polymerase, $\mathrm{MgCl}_{2}$ and annealing temperature, were evaluated. 
One-step RT-LAMP assay and optimization of reaction condition

The RT-LAMP reaction mixture (total volume $25 \mu \mathrm{l}$ ) contained $2 \mu \mathrm{l}$ of target RNA, $0.125 \mathrm{U}$ of AMV reverse transcriptase (Promega, Madison, WI), F3 and B3 (5 pmol/each), FIP and BIP (50 pmol/each), 25 pmol of primer LB, $2.5 \mathrm{mM}$ of dNTP mix (Takara Biotechnology, Dalian, China), $25 \mathrm{mM} \mathrm{MgCl}, 8 \mathrm{M}$ betaine (Sigma, St. Louis, USA), $10 \times$ Bst DNA polymerase buffer, $8 \mathrm{U}$ of Bst DNA polymerase (Takara Biotechnology, Dalian, China), and $\mathrm{ddH}_{2} \mathrm{O}$. Reaction was carried out at $63{ }^{\circ} \mathrm{C}$ for $60 \mathrm{~min}$ and heated at $80{ }^{\circ} \mathrm{C}$ for $5 \mathrm{~min}$. The following indicators of the optimal RT-LAMP amplification were evaluated: ratios of outer and inner primers (1:1 to 1:16); $\mathrm{Mg}^{2+}$ concentration $\left(2-12 \mathrm{mM}\right.$ ) (including the $2 \mathrm{mM} \mathrm{Mg}^{2+}$ in the buffer); dNTPs concentration $(0-2.0 \mathrm{mM})$; amount of template; amount of Bst DNA polymerase $(0.4-8 \mathrm{U})$; temperature $\left(59-66^{\circ} \mathrm{C}\right)$, and RT-LAMP reaction time (10-60 min). All of the precautions of cross-contamination were observed. Each amplicon (5 $\mu 1$ well) was electrophoresed in a $1.5 \%$ agarose gel electrophoresis stained with ethidium bromide (Li and Ren 2011).

Comparison of specificity and sensitivity of virus detection by RT-LAMP and RT-PCR

In order to determine the specificity of the RT-LAMP and RT-PCR assays, the specificity assay was evaluated by using the other three fish viruses, including spring viraemia of carp virus (SVCV), haemorrhagic septicaemia virus (VHS) and koi herpesvirus (KHV). To determine the sensitivity, the template was serially diluted in tenfold decrements down to $10^{-4}$ in $\mathrm{ddH}_{2} \mathrm{O}$ and was used in both assays independently.

\section{Field trial}

To evaluate the reliability of the RT-LAMP and RT-PCR assays as on-site diagnosis system, 48 clinical samples were tested to determine the feasibility, which were collected from grass carps suspected of GCRV infection
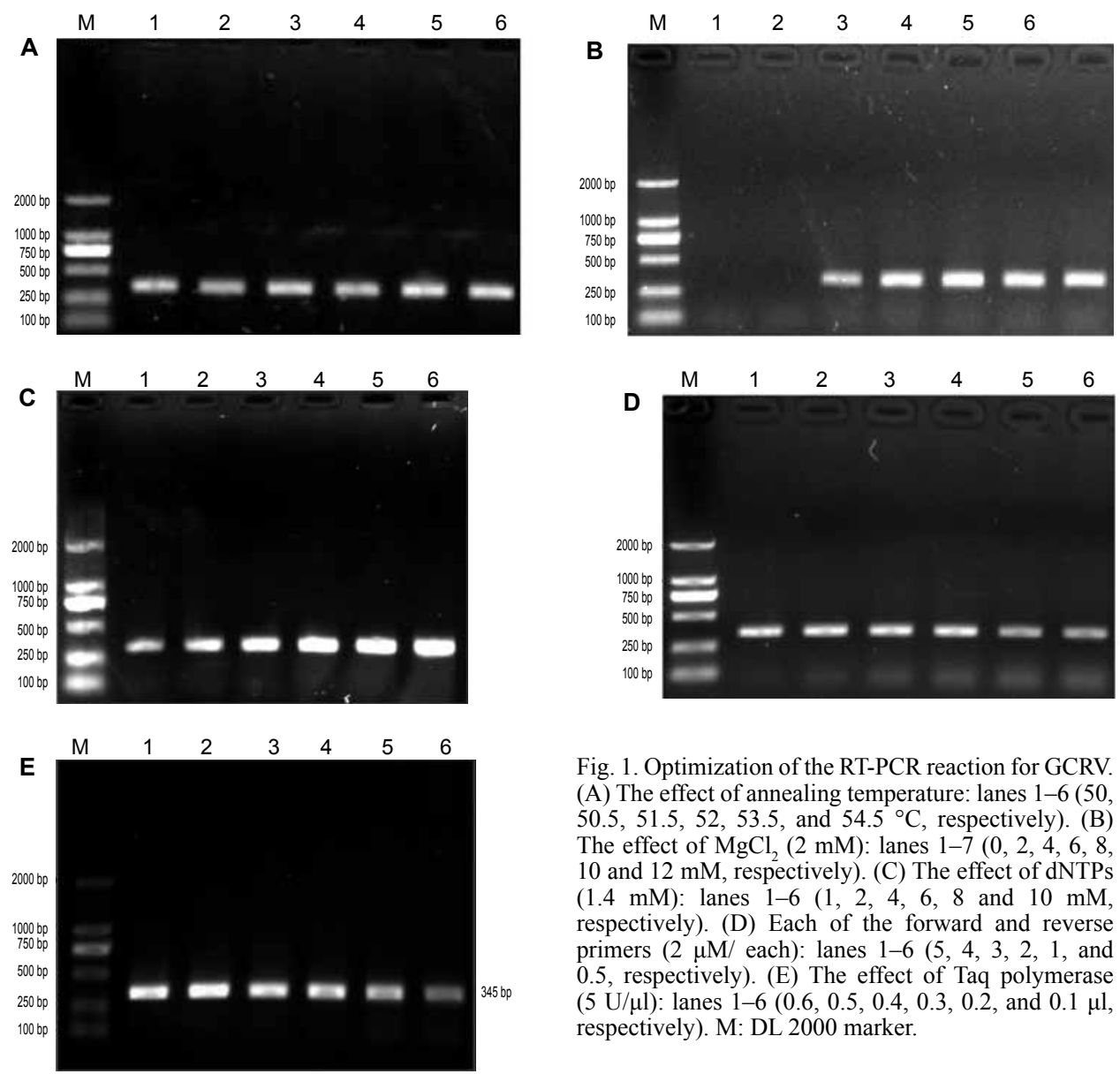

Fig. 1. Optimization of the RT-PCR reaction for GCRV. (A) The effect of annealing temperature: lanes 1-6 (50, $50.5,51.5,52,53.5$, and $54.5^{\circ} \mathrm{C}$, respectively). (B) The effect of $\mathrm{MgCl}_{2}$ (2 mM): lanes 1-7 (0, 2, 4, 6, 8, 10 and $12 \mathrm{mM}$, respectively). (C) The effect of dNTPs (1.4 mM): lanes 1-6 $(1,2,4,6,8$ and $10 \mathrm{mM}$, respectively). (D) Each of the forward and reverse primers $(2 \mu \mathrm{M} /$ each): lanes $1-6(5,4,3,2,1$, and 0.5 , respectively). (E) The effect of Taq polymerase (5 U/ $\mu 1)$ : lanes $1-6(0.6,0.5,0.4,0.3,0.2$, and $0.1 \mu \mathrm{l}$, respectively). M: DL 2000 marker. 
during the outbreak in Meishan, Sichuan Province. Total RNA was extracted from the haematopoietic tissues of these infected grass carps, using TRIzol reagent (Invitrogen, Carlsbad, CA, USA). The established RT-LAMP and RT-PCR assays were implemented under optimized conditions.

\section{Results}

Optimization of the one-step RT-LAMP and RT-PCR assays for detection of GCRV

Grass carp reovirus is a dsRNA virus. In this case reverse transcription was combined with the cDNA amplification using reverse transcriptase, Taq DNA polymerase and Bst DNA polymerase in the RT-PCR and RT-LAMP assay, respectively.

\section{Optimization of the RT-PCR reaction}

Fig. 1A shows the change of amplification product under different annealing temperatures. When RT-PCR was performed, typical single band was formed even at the lowest temperature $\left(50{ }^{\circ} \mathrm{C}\right)$, but clearer and brighter at the last two lines $(53.5$ and $54.5^{\circ} \mathrm{C}$ ). The result showed that the optimal annealing temperature was $54{ }^{\circ} \mathrm{C}$. In terms of reagent concentrations, firstly, regarding the $\mathrm{Mg}^{2+}$ concentration (Fig. 1B), the band was observed when $\mathrm{Mg}^{2+}$ was up to $4 \mathrm{mM}$, and at $8 \mathrm{mM} \mathrm{Mg}^{2+}$ appeared the clearest. There was no significant difference between $\mathrm{Mg}^{2+} 10$ and $12 \mathrm{mM}$. Hence, the concentration of $8 \mathrm{mM}$ $\mathrm{Mg}^{2+}$ was the optimal concentration. Fig. 1C shows the effect of dNTPs concentration, product increased with the increasing of dNTPs concentration (Fig. 1C lane 1-4), but the amplicon had no obvious increase between the dNTPs 8 and $10 \mathrm{mM}$, so the concentration $>8 \mathrm{mM}$ was found to be sufficient (Fig. 1C). The dosage of forward and reverse primers $(2 \mu \mathrm{M} /$ each) was ranging from 1 to $10 \mu \mathrm{M}$, but at $4 \mu \mathrm{M}$ appeared slightly better and gave the maximal reaction product, no additional change was observed when up to $6 \mu \mathrm{M}$. Thus, $6 \mu \mathrm{M}$ was the optimal concentration (Fig. 1D). Lastly, as shown in Fig. 1E, a moderate amount of Taq DNA polymerase can promote a positive reaction (Fig. 1E lane 3-6). The result has shown that 2.5 units were the best concentration. As a whole, the optimal protocol parameters were: annealing temperature at $54{ }^{\circ} \mathrm{C}, \mathrm{Mg}^{2+}$ concentration at $8 \mathrm{mM}$, dNTPs at least $8 \mathrm{mM}$, dosage of forward and reverse primers $6 \mu \mathrm{M}$, and the Taq DNA polymerase the 2.5 units.

\section{Optimization of the RT-LAMP reaction}

Fig. 2A shows the effect of reaction time, no product appeared when the time was less than 30 min (Fig. 2A lane 1-3), apparent LAMP ladder product was not obtained until the time exceeded $40 \mathrm{~min}$ (Fig. 2A lane 4-6). Furthermore, at $40 \mathrm{~min}$ it showed clearer reaction bands (Fig. 2A). The effect of temperature on the reaction was determined. As shown in Fig. 2B, RT-LAMP reaction temperature at $63{ }^{\circ} \mathrm{C}$ generated ladder-like pattern products, but no typical pattern product was detected between $59{ }^{\circ} \mathrm{C}$ and $61{ }^{\circ} \mathrm{C}$. The temperature at $63{ }^{\circ} \mathrm{C}$ gave the optimal amplification. In terms of optimizing $\mathrm{Mg}^{2+}$ concentration (Fig. 2C), similar amounts were produced when $\mathrm{Mg}^{2+}$ was from $2 \mathrm{mM}$ to $4 \mathrm{mM}$. The ladder-like patterns $\left(\mathrm{Mg}^{2+} 6 \mathrm{mM}\right)$ were greater and clearer than the others, so the best concentration of $\mathrm{Mg}^{2+}$ was $6 \mathrm{mM}$. Fig. 2D indicates the yield change under different dNTPs concentration gradients, more amplified ladder-like pattern produced with the increase of dNTPs (Fig. 2D, lines 2-5), and a concentration $>1.6 \mathrm{mM}$ was found to be sufficient and reached saturation. The RT-LAMP worked for all outer-inner primer ratios except the 1:1 ratio (Fig. 2E), but more typical LAMP ladders were observed at the 1:8 ratio. As shown in Fig. 2F, when the concentration of Bst DNA polymerase increased from 1 to $8 \mathrm{U}$, the intensity of the LAMP ladders improved, the more Bst DNA polymerase was used, the clearer product amplified and the less amount of the band was observed. Taken together, the optimal RT-LAMP conditions for the GCRV were determined to incubate at $63{ }^{\circ} \mathrm{C}$ for 

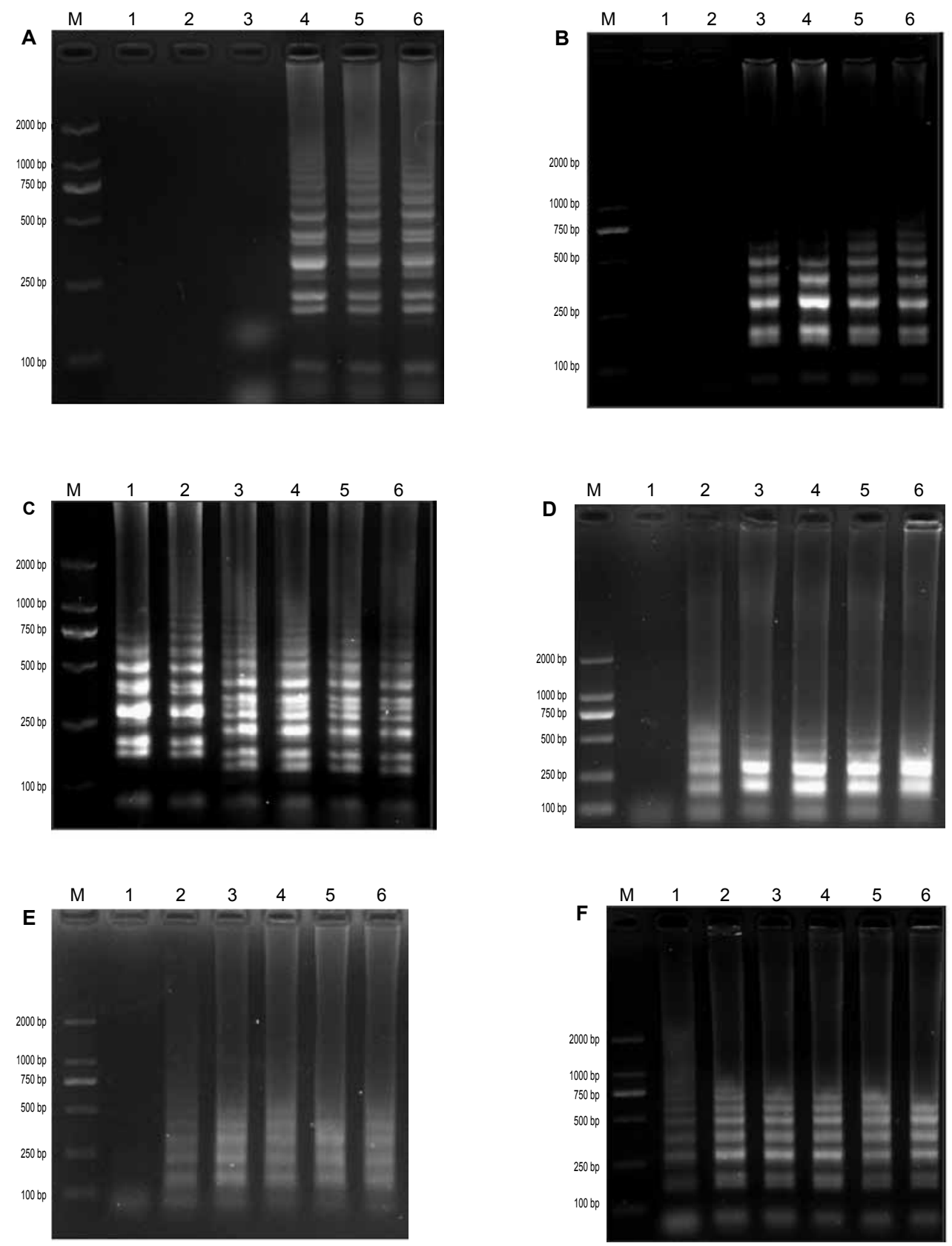

Fig. 2. Optimization of the RT-LAMP reaction for GCRV. (A) The effect of reaction time: lanes 1-6 (10, 20, 30, 40, 50 and $60 \mathrm{~min}$, respectively). (B) The effect of temperature: lanes $1-6\left(59,61,62,63,64\right.$ and $66^{\circ} \mathrm{C}$, respectively). (C) The effect of $\mathrm{MgCl}_{2}$ : lanes 1-6 (12, 10, 8, 6, 4 and $2 \mathrm{mM}$, respectively). (D) The effect of dNTPs: lanes $1-6(0,0.4,0.8,1.2,1.6$ and $2.0 \mathrm{mM}$, respectively). (E) The effect of the ratio of outer and inner primers: lanes 1-6 (1:1, 1:4, 1:8, 1:12, 1:14 and 1:16, respectively). (F) The effect of Bst DNA polymerase ( $8 \mathrm{U} / \mu \mathrm{l})$ : lanes1-6 $(0.05,0.2,0.4,0.6,0.8$ and $1.0 \mu 1$, respectively). M: DL2000 marker. 
$40 \mathrm{~min}$ in the presence of $6 \mathrm{mM} \mathrm{MgCl}, 1.6 \mathrm{mM}$ dNTPs, $0.6 \mathrm{M}$ betaine (data not shown), $5 \mu \mathrm{M}$ each of outer primer, $40 \mu \mathrm{M}$ each of inner primer, and $8 \mathrm{U}$ of Bst polymerase.

\section{Comparison of sensitivity of the RT-PCR and RT-LAMP assays}

In order to determine the sensitivity of detection limit, RT-LAMP and RT-PCR were carried out using serial 10-fold dilutions of the GCRV template. We observed that the RT-LAMP test could detect viral RNA to a dilution of $10^{-4}$ copies (Fig. $3 \mathrm{~B}$ ), but at $10^{-4}$ copies appeared no products by RT-PCR (Fig. 3A). The result indicated that the sensitivity of RT-LAMP assay for detecting GCRV was approximately $\times 10$ higher than that of RT-PCR assay.
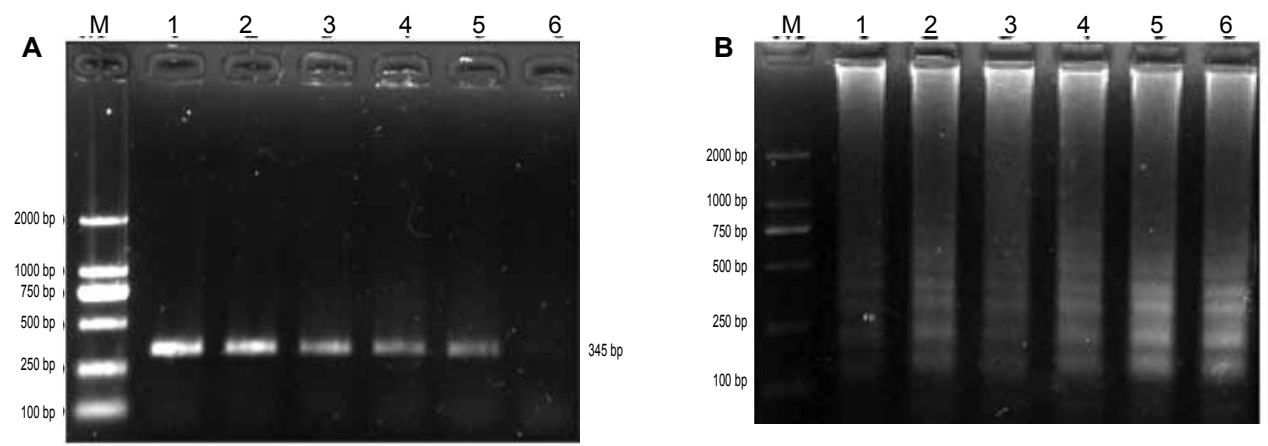

Fig. 3. Sensitivity of the conventional RT-PCR and RT-LAMP assays. (A) Sensitivity of conventional RT-PCR assay; lanes $1-6,10$-fold serial dilutions of the template (10 copies, 1 copy, $10^{-1}$ copies, $10^{-2}$ copies, $10^{-3}$ copies and $10^{-4}$ copies, respectively ); (B) Sensitivity of the RT-LAMP assay; lanes 1-6, 10-fold serial dilutions of the template $\left(10^{-4}\right.$ copies, $10^{-3}$ copies, $10^{-2}$ copies, $10^{-1}$ copies, 1 copy and 10 copies, respectively). M: DL2000 marker.
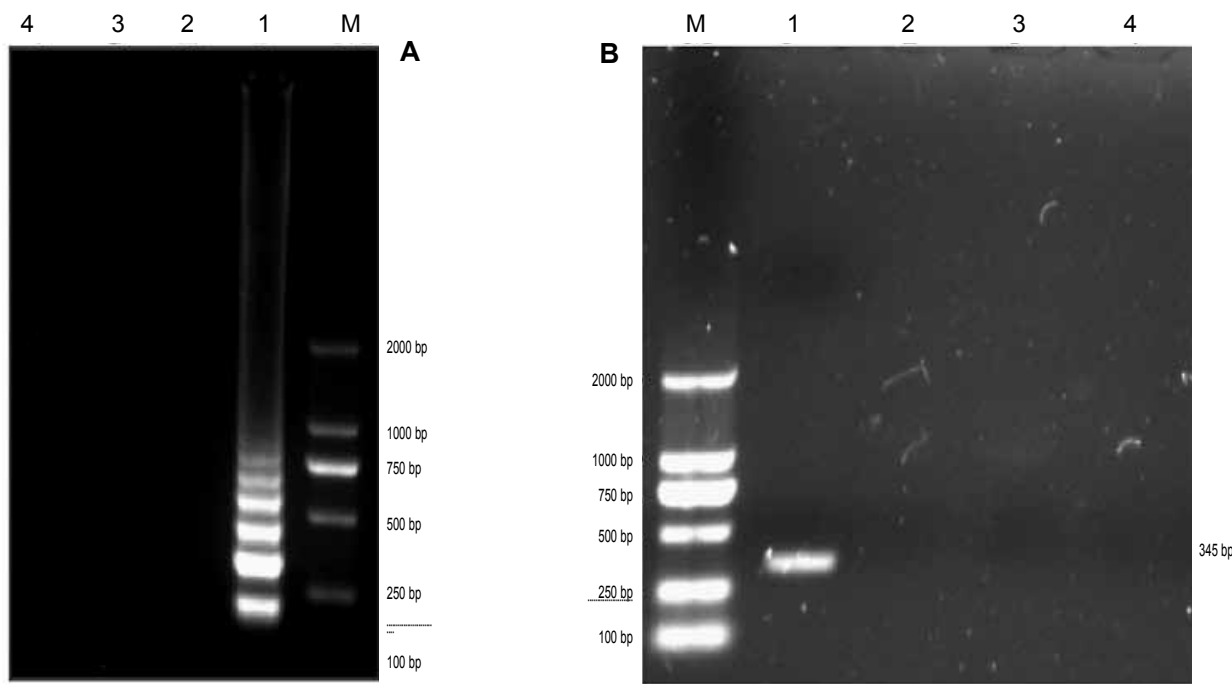

Fig. 4. Specificity of the conventional RT-PCR and RT-LAMP assays. (A) Detection of RT-PCR specificity. 1: reaction of GCRV by RT-PCR; 2: reaction of SVCV by RT-PCR; 3: reaction of VHS by RT-PCR; 4: reaction of KHV by RTPCR; (B)Detection of RT-LAMP specificity. 1: reaction of GCRV by RT-LAMP; 2: reaction of SVCV by RT-LAMP; 3 : reaction of VHS by RT-LAMP; 4: reaction of KHV by RT-LAMP; M: DL2000 marker. 
Comparison of specificity of the RT-PCR and RT-LAMP assays

To determine the specificity of the primers of the target GCRV gene, the other three fish viruses were tested, including SVCV, VHS and KHV. The result showed that only the GCRV was amplified (Fig. 4A line 1 and Fig. 4B line 1), and no amplification product was observed in the other lines (Fig. 4A and 4B). The consequence indicated both RT-PCR and RT-LAMP have a high specificity for detection of GCRV.

Table 2. Detection of 48 grass carp reovirus (GCRV) clinical samples from three different aquaculture farms in the Meishan Sichuan Province including: Dong Shen, Yun Tian, Peng Da. Comparison of reverse transcriptase loop mediated isothermal amplification (LAMP), reverse transcriptase polymerase chain reaction (RT-PCR) and electron microscopy methods.

\begin{tabular}{lrrl}
\hline RT-LAMP & \multicolumn{2}{c}{ RT-PCR } & Total \\
\hline+ & + & - & \\
\hline- & 18 & 0 & 18 \\
Total & 2 & 28 & 30 \\
\hline
\end{tabular}

$+:$ positive samples; - : negative samples, the chi-square test results : $\mathrm{X}^{2}=0.5, P>0.05$

chi-square test results : $\mathrm{X}^{2}=0.5, P>0.05$
The results of the field trial

To determine the feasibility of RTLAMP and RT-PCR assays, a total of 48 samples of grass carp tissues suspected of being infected by GCRV, such as the body surface, fin, branchia and intestine with obvious hyperaemia symptoms, were chosen to be the clinical samples. As shown in Table 2, the chi-square test result showed $\mathrm{X}^{2}=0.5, P>0.05$ (nonsignificant difference). This indicated that both RT-PCR and RT-LAMP were developed successfully to detect GCRV (Table 2).

\section{Discussion}

Grass carp reovirus infection causes extremely high mortality rate in grass carp, and poses a serious threat to the aquaculture industry (Yue et al. 2008). Monitoring programmes have to be enhanced to prevent further disease outbreaks or transmission. This study indicates the RT-LAMP will be a powerful molecular tool for monitoring the health of grass carp and other aquatic animals that may be infected with GCRV.

The primer design plays a more important role in the RT-LAMP reaction. Its reliability mostly depends on the target gene selected. Grass carp reovirus genome possesses 11 segments of linear double-strand RNA; the VP7 genome with a total size of approximately $1 \mathrm{kbp}$ is the most conserved of the viral coat protein which plays a dominant role in complicated pathogenesis of GCRV. We chose the region between 225 and 569 that Motif analysis analyzed as the most conserved for designing the primers, which confirmed the adequate fidelity and high sensitivity of the assay, and reduced the interference caused by genetic mutation, due to the fact that the outer primers and inner primers not only affect the LAMP amplicon in the initiation step, but also impress the cDNA synthesis (Mori and Notomi 2009; Lee et al. 2011b). As the result of the primer optimization in this study it is obvious that the moderate ratio and dosage of primers are very beneficial to the amplification; and conversely, over-dose may inhibit the reaction. In our research, the forward loop primer was not designed. Loop primers only accelerate the amplification reaction and are dispensable for LAMP (Mori and Notomi 2009). The one-step reaction was selected for the following use to reduce the time and simplify the procedure. The RT-LAMP includes two steps: reverse transcription (RT) and LAMP amplification. The optimal temperature $42{ }^{\circ} \mathrm{C}$ of AMV reverse transcriptase is lower than that of Bst DNA polymerase, however, the thermoScript RT has been engineered for reducing RNaseH activity and for higher thermal stability. It can produce high yields of cDNA even at temperatures ranging from $50{ }^{\circ} \mathrm{C}$ to $65{ }^{\circ} \mathrm{C}$ (Lee et al. 2011a; Wang et al. 2011), which allows the AMV RTase and Bst DNA polymerase reaction to be carried out at the same temperature under isothermal conditions. 
Meanwhile, AMV RT used in one-step RT-LAMP for various diagnosis has been reported (Lee et al. 2011a; Song et al. 2012).

With regard to sensitivity and specificity, the study indicated that both methods have the same specificity, whereas the sensitivity of RT-LAMP was $\times 10$ higher than the conventional RT-PCR. The result that RT-LAMP assay has high sensitivity is in consistency with some of the previous reports (Song et al. 2012; Zhang et al. 2012), but different from others (Nkouawa et al. 2009; Ma et al. 2011). This may result from different experimental embodiment, such as gene, primer design, condition reaction. Moreover, in the field trial, we chose the body surface, fin, branchia, and intestine as samples. The chi-square test result also demonstrated that both RT-LAMP and RT-PCR have the same accuracy for detecting GCRV.

RT-LAMP is a rapid, cost-effective, straightforward, specific and sensitive genetic testing technology, which only needs a simple water bath or heating block to provide a constant temperature of $63^{\circ} \mathrm{C}$ for about $1 \mathrm{~h}$ compared to $4-5 \mathrm{~h}$ for RT-PCR. Nevertheless, it may generate a false positive product easily, which results from amplicon handling and the primer dimers; additionally, the use of primer at a high concentration can also inhibit LAMP amplification ( $\mathrm{Njiru}$ et al. 2008). Several previous researchers have made efforts to develop RT-LAMP assay, such as using the restriction enzyme to digest RT-LAMP products (Curtis et al. 2008), establishing one step reaction to decline the risk of cross-contamination to the minimum (Poon et al. 2004). By contrast, the fact that RT-PCR needs a well-equipped laboratory and multiple reaction steps makes cross-contamination less possible to take place. Furthermore, with the widespread use of RT-PCR, it will not be replaced by LAMP easily. In summary, conjugation RT-LAMP (used in primary laboratories) with RT-PCR (used in further molecular-biological experiment) could greatly contribute to epidemiological studies for forecasting and controlling the disease.

\section{Acknowledgement}

This study was supported by grants from the Chang jiang Scholars and Innovative Team Development Plans of the Ministry of Education in China (IRT0848).

\section{References}

Cai S, Lu Y, Wu ZH, Jian J, Wang B, Huang Y 2010: Loop-mediated isothermal amplification method for rapid detection of Vibrio alginolyticus, the causative agent of vibriosis in mariculture fish. Lett App Microbiol 50: 480-485

Curtis KA, Rudolph DL, Owen SM 2008: Rapid detection of HIV-1 by reverse-transcription, loop-mediated isothermal amplification (RT-LAMP). J Virol Methods 151: 264-270

Fujiwara-Nagata E, Eguchi M 2009: Development and evaluation of a loop-mediated isothermal amplification assay for rapid and simple detection of Flavobacterium psychrophilum. J Fish Dis 32: 873-881

Gunimaladevi I, Kono T, Lapatra S, Sakai M 2005: A loop mediated isothermal amplification (LAMP) method for detection of infectious hematopoietic necrosis virus (IHNV) in rainbow trout (Oncorhynchus mykiss). Arch Virol 150: 899-909

Jaroenram W, Kiatpathomchai W, Flegel T W 2009: Rapid and sensitive detection of white spot syndrome virus by loop-mediated isothermal amplification combined with a lateral flow dipstick. Mol Cell Probe 23: 65-70

Lee MS, Lin YC, Lai GH, Lai SY, Chen HJ, Wang MY 2011a: One-step reverse-transcription loop-mediated isothermal amplification for detection of infectious bursal disease virus. Can J Vet Res 75: 122

Lee MS, Yang MJ, Hseu YC, Lai GH, Chang WT, Hsu YH, Lin MK 2011b: One-step reverse transcription loopmediated isothermal amplification assay for rapid detection of Cymbidium mosaic virus. J Virol Methods 173: 43-48

Ma J, Wang W, Zeng L, Fan Y, Xu J, Zhou Y 2011: Inhibition of the replication of grass carp reovirus in CIK cells with plasmid-transcribed shRNAs. J Virol Methods 175: 182-187

Ma M, Ma C, Li M, Wang S, Yang S 2011: Loop-mediated isothermal amplification for rapid detection of Chinese sacbrood virus. J Virol Methods 176: 115-119

Mekata T, Kono T, Savan R, Sakai M, Kasornchandra J, Yoshida T, Itami T 2006: Detection of yellow head virus in shrimp by loop-mediated isothermal amplification (LAMP). J Virol Methods 135: 151-156 
Mori Y, Notomi T 2009: Loop-mediated isothermal amplification (LAMP): a rapid, accurate, and cost-effective diagnostic method for infectious diseases. J Infect Chemother 15: 62-69

Njiru ZK, Mikosza ASJ, Armstrong T, Enyaru JC, Ndungu JM, Thompson ARC 2008: Loop-mediated isothermal amplification (LAMP) method for rapid detection of Trypanosoma brucei rhodesiense. Plos Neglect Trop D 2: e147

Nkouawa A, Sako Y, Nakao M, Nakaya K, Ito A 2009: Loop-mediated isothermal amplification method for differentiation and rapid detection of Taenia species. J Clin Microbiol 47: 168-174

Notomi T, Okayama H, Masubuchi H, Yonekawa T, Watanabe K, Amino N, Hase T 2000: Loop-mediated isothermal amplification of DNA. Nucleic Acids Res 28: e63-e63

Poon LLM, Leung CSW, Tashiro M, Chan KH, Wong BWY, Yuen KY, GuanY, Peiris JSM 2004: Rapid detection of the severe acute respiratory syndrome (SARS) coronavirus by a loop-mediated isothermal amplification assay. Clin Chem 50: 1050-1052

Rangel AAC, Rockemann DD, Hetrick FM, Samal SK 1999: Identification of grass carp haemorrhage virus as a new genogroup of aquareovirus. J Gen Virol 80: 2399-2402

Shivappa R, Savan R, Kono T, Sakai M, Emmenegger E, Kurath G, Levine J 2008: Detection of spring viraemia of carp virus (SVCV) by loop-mediated isothermal amplification (LAMP) in koi carp, Cyprinus carpio L. J Fish Dis 31: 249-258

Soliman H, El-Matbouli M 2006: Reverse transcription loop-mediated isothermal amplification (RT-LAMP) for rapid detection of viral hemorrhagic septicaemia virus (VHS). Vet Microbiol 114: 205-213

Song C, Wan H, Yu S, Han X, Qiu X, Hu Q, Tan L, Ding C 2012: Rapid detection of duck hepatitis virus type-1 by reverse transcription loop-mediated isothermal amplification. J Virol Methods 182: 76-81

Su J, Jang S, Yang C, Wang Y, Zhu Z 2009: Genomic organization and expression analysis of Toll-like receptor 3 in grass carp (Ctenopharyngodon idella). Fish Shellfish Immun 27: 433-439

Watzinger F, Ebner K, Lion T 2006: Detection and monitoring of virus infections by real-time PCR. Mol Aspects Med 27: 254-298

Yue Z, Teng Y, Liang C, Xie X, Xu B, Zhu L, Lei Z, He J, Liu Z, Jiang Y 2008: Development of a sensitive and quantitative assay for spring viremia of carp virus based on real-time RT-PCR. J Virol Methods 152: 43-48

Zhang QL, Yan Y, Shen, JY, Hao GJ, Shi CY, Wang QT, Liu H, Huang J 2012: Development of a reverse transcription loop-mediated isothermal amplification assay for rapid detection of grass carp reovirus. J Virol Methods 187: 384-389

Zhou Y, Zeng L, Fan Y, XU J, Maj J, Luo X, Xiao Y 2011: Establishment of a TaqMan real-time PCR assay for detecting the grass carp reovirus. J Fish China 5: 015 